ments are determined by the fact that they favour both economy and certainty in the operation of the male gametes or spermatozoa, and by their provision of advantageous maternal protection to the minute egg-cells and the early stages of their growth when fertilised. In non-aquatic animals intra-maternal fertilisation of the egg-cells is obligatory.

The egg-cells which are freely discharged and fertilised by free-swimming sperm-cells "in the open" may be called "planktogamic" (plankton= freely swimming), whilst egg-cells which are subjected to the secondary protective arrangements may be called either "hysterogamic" (hysteron=uterus), if fertilised within the oviductal chamber of the mother, or "propylogamic" (propylon=a gateway), if fertilised on the surface of the mother's body or in immediate relation thereto (as in the case of many Crustacea and of some Amphibia).

There is no word in use to indicate the physiological status of an adult female which is no longer a "virgin," but has been "mated" or "covered," and has received into her oviduct sperm-cells from a male. We might designate such a female as a "mate" in contrast to a "virgin," but "mate" is in ordinary use for any kind of comrade. Though the words "wife" and "spouse" have too definite a reference to human legal and social status, yet the Latin word "conjux," implying as it does a "conjugium" (the significance of which is given in Virgil's account of wind-fertilised mares, "sine ullis conjugiis vento gravidæ"), might well be used as the antithesis of "virgo." Any female bearing hysterogamic egg-cells is accordingly a "conjux," whilst one discharging "planktogamic," or it may be "propylogamic," egg-cells is a "virgin."

The existence of "hysterogamesis" leads on to that phenomenon which was by Aristotle regarded as a highly important "differentia" in the classification of animals, and is loosely described as "viviparity." Animals which pass a large part of their embryonic growth within the mother's body and are born naked and with much of the shape and locomotive capacity of the adult are called "viviparous" But really all animals are viviparous, for the birth-product is a living thing whether it is a naked egg-cell or more or less advanced in development. The enclosure of the birth-product in a shell or case, which has given rise to the term "oviparous," is not of any vulue as indicating the real degree of development of the young at birth, for in some cases unfertilised egg-cells, in others mere discs of developing embryonic cells (as in birds, etc.), and in yet other, cases well-shaped young ranging from the early larva of some invertebrates up to the completely formed miniature of the adult, as in some of the shell-bearing snails, may be enclosed within an eggshell when "laid" by the mother. There is accordingly no great general importance to be attached to the distinction between "viviparous" and "oviparous" animals. 'The eggshell has, of course, its protective value, but the exact phase and nature of the living thing within it must be considered in any comparison of the reproductive processes of different animals.

I may now show how far the considerations and the descriptive terms here suggested apply to certain typical cases of what is usually called parthenogenesis, but is better designated "autoblastesis" or "lipospermia."

(x) The greenflies, or Aphides, are, as are all insects, characteristically hysterogamic. They are propagated by males and mating females (conjuges) in autumn. But the spring and summer broods are females only. They are virgins, and produce true egg-cells which are autoblastic and develop into several succeeding generations of impaternate females (lipospermia or partheno- genesis). The egg-cells of these virgin mothers are modified so as to be incapable of zygosis, whilst the maternal structures connected with hysterogamesis (maternal fecundation) are aborted, although the intra. uterine gestation is retained and the young are born naked in a fully formed condition, whence they are said to be "viviparous."

(2) The phyllopod Crustacean Apus normally gives birth to egg-cells encased each in a delicate eggshell. These are autoblastic, and produce with very rare exceptions only impaternate females. At rare intervals, owing to conditions not ascertained, a few impaternate males are hatched from some of the eggs, and "propylogamic" fertilisation of the eggs of some of the virgin mothers of the same generation then takes place.

(3) The breeding queen bee (Apis) and the breeding queens of some other hymenopterous insects are at the same time both parthenogenetic and gamogenetic! They are definitely "conjuges," or mated females, but some of their eggs are hysterogamic and give rise to females only, whilst others are agamic (lipospermic) and give rise by autoblastesis to impaternate males (drones) only. This remarkable double character of the "queen" is due to the fact that the sperm-cells of the drone received by her into her spermatheca can be withheld from contact with the egg-cells about to be laid or admitted to them according to circumstances. Fertilisation of the egg-cell is (to use a French term) "facultative."

(4) Silkworm moths and some other female Lep1doptera sometimes lay eggs without having mated or come into contact with a male. Not infrequently these eggs, which in normal conditions should be hysterogamic, proceed to develop by autoblastesis, and produce impaternate males and females. This lipospermic reproduction is stated to have been experimentally carried out through three successive generations. The autoblastesis can be favoured, if not determined, by brushing the shell of the egg with a camel's-hair pencil.

(5) The female of the common frog is, like that of nearly all bony fishes, in all circumstances a "virgin." Her eggs are planktogamic. Other Amphibia may be propylogamic or even hysterogamic. When received into carefully purified water, the unfertilised eggs of the common frog, which are naturally enveloped, each in a jelly-like coat, can be caused to enter upon the curriculum of cell-division and embryonic growth by scratching the surface of the darkbrown egg-cell with a needle. The impaternate offspring thus produced have been reared to late stages of the tadpole phase, and more rarely to the aduit form. The impaternate or fatherless young thus reared have, so far as at present recorded, always proved on examination to be males.

Other cases of lipospermia or autoblastesis, such as those revealed by the experiments of Loeb, Deslages, and others, could, I think, be with advantage summarised by the use of some such nomenclature as that here suggested. Autoblastesis is contrasted with gamoblastesis, but its occurrence is not "spontaneous." It depends upon either mechanical or various chemical conditions which could be enumerated and classified.

E. Ray LankEster.

\section{The Scandinavian Languages.}

IN the scheme of examination (see NaTuRE, vol. xcix., p. 475), it is curious to see Norwegian and Danish, which have the same dictionary, separated by the very different Swedish language.

August 14.

NO. 2495, VOL. 99] 